\title{
FAKTOR YANG BERHUBUNGAN DENGAN CAKUPAN K4 DI PUSKESMAS SEDAYU II KABUPATEN BANTUL TAHUN 2017
}

\author{
Eniyati $^{1}$, Lily Yulaikhah ${ }^{2}$, Dian Puspitasari ${ }^{3}$ \\ E-mail: eniyati46@yahoo.com \\ D III Kebidanan Universitas Jenderal A. Yani Yogyakarta \\ Jl. Brawijaya Ambarketawang Gamping Sleman Yogyakarta \\ Telp.(0274)4342000
}

\begin{abstract}
Abstrak
Kematian maternal dalam suatu negara merupakan ukuran yang dipergunakan untuk menilai baik buruknya pelayanan kebidanan. Indikator yang digunakan dalam kematian ibu adalah Angka Kematian Ibu (AKI). Pelayanan antenatal merupakan pelayanan kesehatan ibu selama masa kehamilannya, Pelayanan antenatal lengkap jika frekuensi pelayanan minimal 4 kali. Data Profil Kesehatan Dinas Kesehatan Kabupaten Bantu, cakupan K1 sudah $100 \%$, sedangkan cakupan K4 masih di bawah target. Cakupan K 4 terendah di Puskesmas Sedayu II sebesar 72 \%. Jika DO K1-K4 lebih dari $10 \%$ maka perlu penelusuran dan intervensi lebih lanjut.

Penelitian ini bertujuan mengetahui faktor yang berhubungan dengan cakupan K4 di Puskesmas Sedayu II Bantul. Penelitian dilakukan di Puskesmas Sedayu II Kabupaten Bantul dengan rancangan deskriptif korelasi pendekatan cross sectional bersifat retrospektif menggunakan studi dokumen. Populasi seluruh ibu hamil yang melahirkan pada tahun 2017 di wilayah Puskesmas Sedayu II Kabupaten Bantul.

Hasil Penelitian ini yaitu Tidak ada hubungan antara umur dengan K4, nilai $\rho$ value 0.476 . Ada hubungan paritas dengan $\mathrm{K} 4$, nilai $\rho$ value 0.001 . Tidak ada hubungan antara K1 dengan K4, nilai $\rho$ value 0.628 . Tidak ada hubungan antara kasus abortus dengan $\mathrm{K} 4$, nilai $\rho$ value 0.496 .

Tidak ada hubungan antara umur, K1, dan kasus abortus dengan K4. Ada hubungan antara Paritas dengan K4.
\end{abstract}

Kata kunci : $K 4$, Cakupan

\section{Pendahuluan}

Kematian maternal dalam suatu negara merupakan ukuran yang dipergunakan untuk menilai baik buruknya pelayanan kebidanan. Indikator yang digunakan dalam kematian ibu adalah Angka Kematian Ibu (AKI). AKI yaitu jumlah kematian ibu dalam 100.000 kelahiran hidup .' (1) AKI yang tinggi menggambarkan buruknya pelayanan kesehatan pada suatu wilayah.
Tahun 2016 merupakan awal memasuki era SDGs (Sustainable Development Goals) sampai tahun 2030 dan khusus sektor kesehatan terkait kesehatan ibu dan anak merupakan sektor yang dikategorikan di dalam perhatian kesehatan reproduksi dan keluarga berencana. Input SDGs yang diawali tahun 2016 untuk sektor kesehatan diharapkan adalah universal coverage health input ini $\mathrm{di}$ dalamnya adalah akses terhadap kualitas pelayanan kesehatan dasar yang aman, selain 
adanya akses obat-obatan yang berkualitas dan aman untuk semua masyarakat.

Pelayanan antenatal merupakan pelayanan kesehatan oleh tenaga kesehatan untuk ibu selama masa kehamilannya, dilaksanakan sesuai dengan standar pelayanan antenatal yang ditetapkan dalam Standar Pelayanan Kebidanan (SPK). Pelayanan antenatal yang sesuai standar meliputi timbang berat badan, pengukuran tinggi badan, tekanan darah, nilai status gizi (ukur lingkar lengan atas), tinggi fundus uteri, menentukan presentasi janin dan denyut jantung janin (DJJ), skrining imunisasi TT dan pemberian imunisasi, pemberian tablet zat besi minimal 90 tablet selama kehamilan, test laboratorium, tata laksana kasus, dan temu wicara (konseling).

Pelayanan antenatal dianggap lengkap jika dilakukan oleh tenaga kesehatan dengan frekuensi pelayanan minimal 4 kali selama kehamilan. Kunjungan antenatal yang dianjurkan yaitu 1 kali pada triwulan pertama, 1 kali pada triwulan kedua, dan 2 kali pada triwulan ketiga. Standar waktu kunjungan tersebut diharapkan dapat menjamin atau memberikan perlindungan ibu hamil, seperti deteksi dini faktor risiko, pencegahan dan penanganan komplikasi.

Evaluasi pencapaian program pelayanan kesehatan ibu hamil dapat dinilai dengan indikator cakupan K1 dan K4 oleh tenaga kesehatan. K1 merupakan indikator untuk mengetahui jangkauan pelayanan antenatal serta kemampuan program menggerakkan masyarakat. Cakupan K4 merupakan indikator diketahuinya cakupan pelayanan antenatal yang lengkap, sehingga dapat menggambarkan tingkat perlindungan ibu hamil di suatu wilayah.

Data yang diperoleh dari Profil Kesehatan Dinas Kesehatan Kabupaten Bantul tahun 2016, cakupan ibu hamil K1 tahun 2015 dilaporkan mencapai $100 \%$ sehinggan telah mencapai target K1 $95 \%$. Cakupan ibu hamil K4 tahun 2016 dilaporkan sebesar 92,08 \%, kurang dari target K4 95 \%. Cakupan K4 ibu hamil tertinggi terdapat di wilayah kerja Puskesmas Kasihan I sebesar 100 \%. Cakupan kunjungan terendah terdapat di wilayah kerja Puskesmas Sedayu II sebesar 72 \%. Presentase Drop Out (DO) K1-K4 sebesar 23 \%. Jika DO K1-K4 lebih dari $10 \%$ maka perlu penelusuran dan intervensi lebih lanjut. ${ }^{(2)}$

Cakupan pelayanan antenatal adalah persentasi ibu hamil yang telah mendapatkan pemeriksaan kehamilan oleh tenaga kesehatan di suatu wilayah kerja. Cakupan K1 adalah cakupan ibu hamil yang pertama kali mendapatkan pelayanan antenatal oleh tenaga kesehatan di suatu wilayah kerja pada kurun waktu tertentu. Cakupan K4 adalah cakupan ibu hamil yang mendapatkan pelayanan antenatal sesuai dengan standar paling sedikit empat kali di suatu wilayah kerja pada kurun waktu tertentu. ${ }^{(3)}$

Indikator K1 digunakan untuk mengetahui jangkauan pelayanan antenatal serta kemampuan program dalam menggerakkan masyarakat. Indikator K4 
menggambarkan kemampuan manajemen ataupun kelangsungan program KIA

Tujuan dari penelitian ini adalah diketahuinya Faktor Yang Berhubungan Dengan Cakupan K4 Di Puskesmas Sedayu II Kabupaten Bantul Tahun 2017.

\section{Metode Penelitian}

Jenis penelitian dalam penelitian ini adalah deskriptif korelasi yakni penelitian yang bertujuan untuk menemukan ada tidaknya hubungan dan apabila ada, seberapa tingkat keeratannya hubungan serta berarti atau tidak ada hubungan itu. ${ }^{(4)}$ Teknik pengambilan data dilakukan melalui pendekatan cross-sectional dan bersifat retrospektif dengan menggunakan data rekam medik. Populasi dalam penelitian ini adalah data semua ibu hamil pada tahun 2017 di wilayah Puskesmas Sedayi II Kabupaten Bantul yang berjumlah 320 orang. Metode pengambilan sampel menggunakan Consecutive Sampling yaitu tehnik pengambilan sampel berdasarkan criteria yang telah ditentukan sampai kurun waktu tertentu sehingga jumlah sampel yang diperlukan terpenuhi. Analisa data yang dipergunakan adalah univariat untuk menggambarkan distribusi frekuensi masing-masing variabel yang diteliti dan bivariat untuk menganalisa variabel bebas dengan variabel terikat. Teknik pengujian dua variabel tersebut dengan korelasi Chi Square

\section{Hasil dan Pembahasan}

a. Distribusi Frekuensi Berdasarkan Karakteristik Responden.

Tabel 1. Karakteristik Responden

\begin{tabular}{clcc}
\hline No & $\begin{array}{c}\text { Karakteristik } \\
\text { Responden }\end{array}$ & $\begin{array}{c}\text { Frekuensi } \\
(\mathrm{n})\end{array}$ & $\begin{array}{c}\text { Persentase } \\
(\%)\end{array}$ \\
\hline 1 & Umur & & \\
& $<20$ tahun & 10 & 3.1 \\
& 20-35 tahun & 260 & 81.3 \\
& $>35$ tahun & 50 & 15.6 \\
& Jumlah & $\mathbf{3 2 0}$ & $\mathbf{1 0 0}$ \\
2 & Paritas & & \\
& Primipara & 110 & 34.3 \\
& Multipara & 205 & 56 \\
& Grande multipara & 5 & 1.6 \\
& Jumlah & $\mathbf{3 2 0}$ & $\mathbf{1 0 0}$ \\
\hline
\end{tabular}

Berdasarkan Tabel 1 didapatkan bahwa sebagian responden penelitian berumur 20-35 tahun sebanyak $81.3 \%$ (260 orang), dan sebagian besar dengan paritas multipara sebanyak $56 \%$ ( 205 orang).

Berdasarkan hasil penelitian didapatkan bahwa sebagian responden berumur 20-35 tahun. Umur dengan rentang 20-35 tahun merupakan umur yang aman untuk kehamilan, sehingga dikatakan umur yang tidak berisiko. Semakin cukup umur, tingkat kematangan dan kekuatan seseorang akan lebih matang dalam berpikir dan bekerja. Bertambahnya umur seseorang maka kematangan berpikir semakin baik, sehingga termotivasi dalam memeriksakan kehamilan dan mengetahui pentingnya Antenatal Care (ANC). ${ }^{(5)}$

Paritas merupakan jumlah anak yang dilahirkan oleh ibu. Ibu yang pertama kali hamil berbeda dengan ibu yang sudah pernah mengalami kehamilan sebelumnya. Ibu yang pertama kali melahirkan merasa membutuhkan dalam 
pemeriksaan kehamilan, dan merasa betapa pentingnya kunungan ANC. Hasil uji statistic menunjukkan bahwa sebagian besar dengan paritas multigravida.

b. Variabel Penelitian.

1) Tabel 2. Distribusi Frekuensi Kasus Abortus Di Puskesmas Sedayu II Bantul Tahun 2017

\begin{tabular}{lcc}
\hline Kriteria & Frekuensi (n) & Persentase (\%) \\
\hline Abortus & 2 & 0.6 \\
Tidak Abortus & 318 & 94.0 \\
Jumlah & $\mathbf{3 2 0}$ & $\mathbf{1 0 0}$ \\
\hline
\end{tabular}

Berdasarkan Tabel 2. didapatkan bahwa 0.6 $\%$ (2 orang) mengalami abortus.

2) Tabel 3. Distribusi Frekuensi Kunjungan K1 dan K4

\begin{tabular}{lcc}
\hline Kunjungan & Frekuensi (n) & Persentase (\%) \\
\hline 1. K 1 & 167 & 52.2 \\
Murni & 153 & 47.8 \\
Akses & $\mathbf{3 2 0}$ & $\mathbf{1 0 0}$ \\
Jumlah & & \\
2. K 4 & 60 & 18.8 \\
Ya & 260 & 81.2 \\
Tidak & $\mathbf{3 2 0}$ & $\mathbf{1 0 0}$ \\
Jumlah & & \\
\hline
\end{tabular}

Berdasarkan Tabel 3. menunjukkan bahwa sebagian besar responden penelitian melakukan kunjungan K1 murni sebanyak $52.2 \%$ (167 orang). Sebagian besar responden $81.2 \%$ (260 orang) tidak melakukan kunjungan K4. K1 Kehamilan adalah kontak ibu hamil yang pertama kali dengan petugas kesehatan untuk pemeriksaan kesehatan ibu hamil sesuai standar pada trimester pertama, dengan usia kehamilan 1 sampai 12 minggu. Kunjungan K1 dibagi menjadi dua, yaitu kunjungan K1 murni dan kunjungan K1 Akses. ${ }^{(6)}$ Berdasarkan distribusi frekuensi sebagian besar ibu hamil merupakan K1 murni sebanyak 167 orang. Ibu hamil melakukan kontak pertama dengan tenaga kesehatan pada trimester I. Ibu hamil dengan K1 Murni yang melakukan K4 sebanyak 33 orang (10\%).

3) Tabel 4. Hubungan Karakteristik Responden dengan kunjungan K4

\begin{tabular}{cccccc}
\hline Variabel & $\begin{array}{c}\text { Kunju } \\
\text { ngan } \\
\text { K 4 }\end{array}$ & $\begin{array}{c}\text { Tidak } \\
\text { kunjung } \\
\text { an K 4 }\end{array}$ & Jumlah & $\mathrm{X}^{2}$ & $\begin{array}{c}\text { Nilai } \\
\rho\end{array}$ \\
\hline $\begin{array}{c}\text { Umur } \\
<20 \text { tahun }\end{array}$ & 1 & 9 & 10 & 1.4 & 0.476 \\
$\begin{array}{l}20-35 \\
\text { tahun }\end{array}$ & 47 & 213 & 260 & 84 & \\
$>35$ tahun & 12 & 38 & 50 & & \\
$\quad$ Total & 60 & 260 & 320 & & \\
\hline $\begin{array}{c}\text { Paritas } \\
\text { Primipara }\end{array}$ & 15 & 95 & 110 & 14. & 0.001 \\
$\begin{array}{l}\text { Multipara } \\
\text { Grande }\end{array}$ & 41 & 164 & 205 & 4 & \\
multipara & & 1 & 5 & & \\
Total & 60 & 260 & 320 & & \\
\hline
\end{tabular}

Berdasarkan Tabel 4. menunjukkan bahwa tidak ada hubungan antara umur dengan kunjungan K4. Berdasarkan analisis data pada umur, didapatkan $\mathrm{X}^{2}$ sebesar 1.484. $\mathrm{X}^{2}>\mathrm{X}^{2}$ tabel maka Ho ditolak. $1.484<3.84$ maka Ho diterima, artinya tidak ada hubungan antara umur dengan kunjungan K4. Nilai $\rho$ value sebesar 0.476 , sehingga lebih besar 0.05 maka tidak ada hubungan antara umur dengan K4. Berdasarkan analisis data pada paritas, didapatkan $\mathrm{X}^{2}$ sebesar 14.4. $\mathrm{X}^{2}>\mathrm{X}^{2}$ tabel maka Ho ditolak. $14.4>3.84$ maka Ho ditolak, artinya ada hubungan antara paritas dengan kunjungan K4. Nilai $\rho$ value sebesar 0.001, sehingga lebih kecil dari 0.05 maka ada hubungan antara paritas dengan K4.

Penelitian yang dilakukan oleh Ministi tahun 2017 juga menyatakan ada hubungan antara paritas dengan keteraruran pemeriksaan Antenatal Care (ANC). Ibu yang sudah pernah hamil dan sudah pernah melahirkan lebih dari satu orang mempunyai anggapan bahwa ia sudah berpengalaman sehingga 
tidak termotivasi untuk memeriksakan kehamilannya. $^{(7)}$

4) Tabel 5. Hubungan Kunjungan K 1 dengan Kunjungan K4

\begin{tabular}{cccccc}
\hline Variabel & $\begin{array}{c}\text { Kunju } \\
\text { ngan } \\
\text { K 4 }\end{array}$ & $\begin{array}{c}\text { Tidak } \\
\text { kunjung } \\
\text { an K 4 }\end{array}$ & Jumlah & $\mathrm{X}^{2}$ & $\begin{array}{c}\text { Nilai } \\
\rho\end{array}$ \\
\hline K1 & & & & & \\
Murni & 23 & 134 & 167 & 0.2 & 0.628 \\
Akses & 27 & 126 & 153 & 34 & \\
Total & 60 & 260 & 320 & & \\
\hline
\end{tabular}

Berdasarkan Tabel 5. menunjukkan bahwa tidak ada hubungan antara K1 dengan kunjungan K4. Berdasarkan analisis data pada $\mathrm{K} 1$, didapatkan $\mathrm{X}^{2}$ sebesar 0.234. $\mathrm{X}^{2}>\mathrm{X}^{2}$ tabel maka Ho ditolak. 0.234 $>3.84$ maka Ho diterima, artinya tidak hubungan antara K1 dengan kunjungan K4. Nilai $\rho$ value sebesar 0.628, sehingga lebih besar dari 0.05 maka tidak ada hubungan antara K1 dengan K4. Tidak adanya hubungan antara K1 dengan K4 di Puskesmas Sedayu II tahun 2017 disebabkan karena pasien merupakan pasien rutin di Praktik Mandiri Bidan (PMB). Pasien melakukan kunjungan di Puskesmas hanya untuk pemeriksaan ANC lengkap, sehingga pasien melakukan kunjungan ulang bukan di Puskesmas kecuali ditemukan permasalahan pada pasien yang memerlukan penanganan lanjut.

5) Tabel 6. Hubungan Abortus dengan Kunjungan K4

\begin{tabular}{lllllc}
\hline Variabel & $\begin{array}{c}\text { Kunju } \\
\text { ngan } \\
\text { K 4 }\end{array}$ & $\begin{array}{c}\text { Tidak } \\
\text { kunjung } \\
\text { an K 4 }\end{array}$ & Jumlah & $\mathrm{X}^{2}$ & $\begin{array}{c}\text { Nilai } \\
\rho\end{array}$ \\
\hline Abortus & 0 & 2 & 2 & 0.4 & 0.496 \\
Tidak & 60 & 258 & 318 & 64 & \\
$\begin{array}{c}\text { Abortus } \\
\text { Total }\end{array}$ & 60 & 260 & 320 & & \\
\hline
\end{tabular}

Berdasarkan Tabel 6. menunjukkan bahwa tidak ada hubungan antara kasus abortus dengan kunjungan K4. Berdasarkan analisis data pada kasus abortus, didapatkan $\mathrm{X}^{2}$ sebesar $0.464 \mathrm{X}^{2}>\mathrm{X}^{2}$ tabel maka Ho ditolak. $0.464<3.84$ maka Ho diterima, artinya ada tidak hubungan antara kasus abortus dengan kunjungan K4. Nilai $\rho$ value sebesar 0.496 , sehingga lebih besar dari 0.05 maka tidak ada hubungan antara kasus abortus dengan K4. Pasien hamil di Puskesmas Sedayu II Bantul yang mengalami komplikasi abortus hanya $0.6 \%$ atau sebanyak dua pasien, sehingga tidak memengaruhi K4. Pasien yang melakukan K1 tetapi mengalami abortus atau keguguran secara otomatis sudah tidak melakukan kunjungan K4.

\section{Kesimpulan}

Tidak ada hubungan antara umur, K1, dan kasus abortus dengan K4. Ada hubungan antara Paritas dengan K4.

\section{Daftar Pustaka}

[1] Wiknjosastro, H. 2009. Ilmu Kebidanan. Edisi ke-4 Cetakan ke-2. Jakarta: Yayasan Bina Pustaka.

[2] Dinas Kesehatan Provinsi Jawa Tengah.2016. Profil Dinkes Provinsi Jawa Tengah. Dinkes Provinsi Jawa Tengah: Semarang.

[3] Depkes RI. 2009. Pedomen Wilayah Setempat Kesehatan Ibu dan Anak (PWSKIA). Direktorat Bina Kesehatan Ibu: Jakarta.

[4] Arikunto, S. 2010. Prosedur Penelitian Suatu Pendekatan Praktik. Edisi Revisi VI. Jakarta: Rineka Cipta. 
[5] Padila, 2014. Buku Ajar Keperawatan Maternitas. Yogyakarta: Nuha Medika.

[6] Meilani, dkk. 2009. Kebidanan Komunitas. Fitramaya: Yogyakarta.

[7] Junga, M.R. 2017. Faktor-Faktor Yang Berhubungan Dengan Keteraturan Pemeriksaan Antenatal Care (ANC0 Ibu Haml Trimester III Di Puskesmas Ranotana Weru Kota Manado. Jurnal Keperawatan, volume Nomor 1. https//media.neliti.com. Diakses tanggal 4 November 2017 jam 18.00. 